\title{
Family memories on social hospitality dimensions while on holiday
}

\author{
Abstract \\ This paper focuses on neglected social hospitality dimensions of food and accommodation on \\ family holidays. Holidays signify concentrated periods of family time allowing for more \\ shared food experiences but also necessitating more confined living spaces compared to \\ home. A whole-family methodology was used as a critical and holistic approach to \\ understanding the holiday experiences of 10 families. Positive and negative memories of \\ hospitality encounters for different family members are illustrated through the emotive \\ concepts of commensality and spatiality highlighting their embodied, visible and interactive \\ aspects. Family meals take on symbolic and publicly celebrated characteristics whereas \\ shared accommodation space is privately contested. The theoretical implications of the \\ antithetical nature of family hospitality dimensions are further discussed and the family \\ tourism research agenda further developed.
}

Key words: Accommodation space, children, commensality, embodiment, family holiday experiences, social hospitality, sociality, spatiality, whole-family methodology 


\section{Introduction}

Family holidays involve leisure travel away from home for more than one day taken within the context of a family group (at least one child and one adult) (Schänzel et al., 2012). Families travelling with dependent children represent one of the largest markets for the tourism and hospitality industry. Children and families form the closest and most important emotional bond in humans and it is this relationship that drives the demand. For example, family holidays in Britain constitute 25\% of all domestic tourism trips (VisitBritain, 2011).

There has been increased research of everyday family life experiences such as family meals (Davidson and Gauthier, 2010) as well as research into the negotiation of space in the family home (Munro and Madigan, 1999), yet researchers have not followed suit within an away from home dimension. The family holiday meal time and family holiday space are poorly understood. On family holidays, shared meals as commensality experiences can assume highly symbolic celebratory characteristics whereas accommodation spatiality can be contested and impact negatively on experiences and memories. Holidays typically necessitate living in much smaller and more restricted accommodation spaces than at home (Lehto et al., 2012) as well as signifying condensed periods of time with family permitting more frequent and potentially time-rich shared food experiences. Their investigation is therefore significant.

This paper responds to calls for bringing the sociality and domesticity of families into the tourism research agenda (Obrador, 2012) and aids in understanding social interactions on holiday (Blichfeldt and Mikkelsen, 2013) amongst parents and their children. Through a focus on the social dimensions of hospitality, it aims to illustrate and discuss family group experiences of food and accommodation on holiday. The study reported here highlights neglected family group perspectives as played out in hospitality encounters whilst on holiday 
and fits with those who argue that hospitality can act as a social lens on the family (Lashley et al., 2007). It is based on a whole-family study (10 families with 20 parents and 20 children) within different holiday situations in New Zealand and overseas which recognises the necessity of considering all family members in tourism research (Schänzel et al., 2012)

\section{Hospitality dimensions on family holidays: Family meals and accommodation}

The literature on hospitality dimensions of family holidays is surprisingly thin. The following section reviews those themes considered of greatest relevance to understanding the phenomenon. Little research has been conducted on the social significance of holidays that involve parents and children (Carr, 2011). Most family tourism research is market- and consumer-driven and focused on the themes of individual decision processes and has rarely attempted to understand family tourism behaviour as a whole as argued by Lehto et al. (2012). The predominance of tourism investigation that focuses on the individual has effectively de-socialised tourist subjects rendering such approaches unsuitable for understanding family groups (Obrador, 2012). Yet, family holidays stand out as more memorable and purposeful family social times (Shaw et al., 2008), allowing for increased opportunities for shared meals but also generally more time together in confined sleeping arrangements such as caravans and self-contained cabins (Backer and Schänzel, 2013).

There are studies on family holiday experiences that are mainly informed by a feminist perspective focused on mothers' experiences (e.g., Davidson, 1996, Deem, 1996, Small, 2005). Little is published on the holiday experiences of fathers apart from their joint parenting voice (Schänzel and Smith, 2011). Few studies investigate the family holiday experiences of children (e.g., Blichfeldt et al., 2011, Carr, 2011, Hilbrecht et al., 2008, Small, 2008). There is increasing research on the parents and group perspective of family holiday experiences (e.g., Gram, 2005, Larsen, 2013, Shaw et al., 2008). However, little attention is 
given to the experiences of all family members and how family group dynamics can affect individual holiday experiences as Pritchard and Havitz (2006) have argued. Examining the generic sociological and cultural literature, it is found that there is extensive research into meal times and to a lesser extent spatiality within the family home environment. These principal themes are reviewed below to inform a deeper understanding of the importance of meals and negotiation of space on family holidays.

There has only been scant emphasis on holiday hospitality dimensions. Meal times have been mentioned in studies on family holiday experiences (e.g., Carr, 2011, Haldrup, 2004, Hilbrecht et al., 2008) but have not been the focus. Gram (2005) identifies the importance of the family eating ice cream as signifying an important moment of togetherness. Alternatively, Carr (2011) analyses how the tourism industry caters for children's needs. While tourism brochures and travel guide books portray eating out as "family fun” (Heimtun, 2010), there is acknowledgement that responsibility for feeding the family on holiday is perceived as work by mothers (see Mottiar and Quinn, 2012, Small, 2005).

An important theme connected with food is that of memory (Holtzman, 2010) and this relationship may be conjectured as of special importance in relation to family holiday meals. Food is identified with the evocation of nostalgic associations such as Australian immigrants associating certain foods with their homeland (Bell and Valentine, 1997) and "nostalgia for family, home and friendships” (Lashley et al., 2003). Notably, for reasons of human safety, bad food may be especially memorable compared to memories of good food (Holtzman, 2010). Yan (1997) highlights how foods may be deemed and remembered as “exotic” concerning cultural difference but also associated eating manners, environment and patterns of social interaction. Indeed, Cohen and Avieli (2011) argue that tourists travel in quest of 
novelty and strangeness which extends to food. Braithwaite (2003) provides insights into memories of hospitable occasions which signal the special place of the meal in hospitality no matter what the environmental circumstances. A rare study of most memorable meal experiences (Lashley et al., 2003) relates how family holiday meal experiences are subordinated to other dimensions, for example, a scenic location.

More generally, food is associated with the maintenance of family relationships which are intertwined in recollections and assist in developing family cohesion (Bell \& Valentine, 1997). Special social occasions are often marked by particular foods (Mennell et al., 1992), and family rituals such as special meal occasions can convey messages about group identities (Fiese et al., 2002). Conversely, it has been suggested by Burgoyne and Clarke (1983) that food and mealtimes can be the focus of tensions within a marriage, and family meals may be “emotionally charged and politically contested” (Jackson, 2009: 2). Indeed, the family meal is considered as “a largely mythological family eating event” (Blake et al., 2009). Little research has been conducted into the generationally nuanced food moralities within family life from the perspectives of the children, such as their preference for junk food compared to a healthy eating discourse (Curtis et al., 2010).

The increasing popular and academic literature on family meals is spurred by its perceived reduced frequency (Davidson and Gauthier, 2010) while also documenting a number of benefits of family meals such as academic success and healthy food selections (Fruh et al., 2011), further contributing to its mythological status. Time use studies indicate a decline of shared meal times despite eating still being the most important activity done as a family (Mestdag and Vandeweyer, 2005). The process of preparing and receiving food is deemed to contribute to the maintenance of social structures (Mennell et al., 1992), including that of the 
family (Beardsworth and Keil, 1997). Davidson and Gauthier (2010) suggest family meals enhance the socio-emotional and cognitive development of children. Through food consumption participants learn how to perform social roles (Beardsworth and Keil, 1997). Family meals thus have a role to play in communicating cultural values and in developing individual identity (Bell and Valentine, 1997). Family meals are also considered part of daily routines contributing to the rhythms of the family household leading to the construction of the meaning of "home” (Douglas, 1991).

The sharing of meals is associated with various forms of symbolism. Douglas (1975) suggests such sharing determines the boundaries of the existence of the family symbolically and emotionally. Family meals have also been viewed as symbolizing and communicating social distinctions through the choice of food consumed (Beardsworth and Keil, 1997) and also family solidarity (Wood, 1995). An important recent theme is in relation to the way that families 'display' themselves in public through events such as the family eating together (Finch, 2007) or the family usage of Western-style fast food restaurants in Beijing (Yan, 1997). There are underlying cultural discourses about proper and improper families in that feeding one’s family well can be a visible sign of good parenting (James and Curtis, 2010). Indeed, Seymour (1983) views the meal as involving role performance, how participants present themselves to the outside world. A wider perspective is adopted by Bildtgåård (2010) who suggests that “... with every meal, the individual reproduces the community he belongs to - household, extended family, region, nation” (p. 216). Accordingly, one reading of the family holiday meal may be that of reinforcing the family identity in response to others.

Another important theme associated with shared meals is commensality, i.e. the practice of eating together (Sobal and Nelson, 2003) and promoting communal solidarity, sociability and 
socialisation that reflect the social organisation of societies (Danesi, 2012). Such bonding is also connected with social capital in that social relations integrate people (Putnam, 2000) and is increasingly associated with social tourism (see Minnaert et al., 2009) and family tourism (see Schänzel et al., 2012). Mennell et al. (1992) consider commensality as "a perilous notion” since "inclusion implies exclusion” (p. 17), a dimension at the heart of any hospitality event (Lashley et al., 2007). The concept of commensality therefore supports the idea of the symbolic importance of the family meal while on holiday.

Concerning accommodation space, there have been studies on the types used on family holidays (e.g., Mintel, 2004), accommodation arrangements (e.g., Cullingford, 1995), impact of accommodation choice on household responsibilities (e.g., Mottiar and Quinn, 2012) and specific accommodation forms such as campgrounds (e.g., Collins and Kearns, 2010) but none of these studies describe the qualitative experiences of the families studied. Obrador (2012) and Backer and Schänzel (2013) mention the potential of inadequate accommodation facilities for creating conflict and stresses on family holidays. Few studies have looked into the relationship between accommodation space and family group dynamics, and spatiality, i.e. lived and felt space (Van Manen, 1990), as a theme is absent in family tourism research. Carr (2011) surveys major themes identified in a limited family literature on tourism accommodation. Currently, accommodation providers who promote their establishments as family-friendly in practice offer little more than cramped family rooms. Emphasis exists upon provision of certain children-oriented activities taking place outside the bedroom accommodation such as children's clubs or swimming pools.

Carr (2011) and Obrador (2012) found in their studies that the family rooms offered are not conducive to enabling children and adults with different sleeping times to share 
accommodation harmoniously. In addition, needs of adolescents in terms of activities are generally overlooked and there is a lack of research into sleep in tourism (Valtonen and Veijola, 2010). Backer and Schänzel (2013) identify negative aspects such as including facilities that are neither safe nor child-friendly and conditions not conducive to sleep. Against this background, a growing number of hotels are identified by Carr (2011) as seeking to meet the individual needs of children and their parents through the design of familyfriendly rooms enabling a degree of privacy. Nevertheless, it seems families generally opt for forms of commercial accommodation that offer flexibility and low levels of hospitality organisational control, such as self-catering and camping (see Mottiar and Quinn, 2012; Backer and Schänzel, 2013).

It is arguable that there is a fundamental lack of understanding in the tourism literature with regard to the deeper significance of accommodation for the family. Drawing upon Lefebvre (1991), Morgan (2011) suggests that domestic space can be read at three levels: practical, symbolic and imaginary. Practical is concerned with family practices, such as ways in which space is organised to achieve practical ends. Symbolic refers to the meanings attached to and discourses regarding space and family practices, for instance, ideas about a proper family. Imaginary is concerned with the individual ideals of family life that can be located in different time dimensions. Accommodation space therefore is more than a functional or simply a territorial space (Giorgi et al., 2007); rather, it is a space that has social, cultural and historical significance (Moore, 2000). Acknowledgement must be given here to the realities of many families living in cramped living conditions, e.g. emergency accommodation and the disadvantaged (Halpenny et al., 2002), and the ensuing tensions which inevitable arise. 
The design of accommodation space and how this shapes or reflects the body in family practices is also drawing increasing attention in sociological enquiry (Morgan, 2011). Haldrup (2004) identifies tourists with an emphasis upon transformation of the holiday place into "a home away from home” (p. 437) from which to explore the locality. This signifies ‘not only an escape from an everyday-home but also for a holiday-home’ (Larsen, 2013: 16). Giorgi et al. (2007) advise that family cultural identities are emergent from house space and families define themselves through such spaces. Holloway and Valentine (2000) perceive home space for children as one founded on relations of power and control. A spatial analytical approach to domestic family life indicates most family time is spent in a small spectrum of home spaces, such as kitchens and living-rooms (Broege et al., 2007) and that modern family houses allow for increasing privatisation of family members' spaces, such as bedrooms (Graesch, 2004). Graesch (2004) identifies how spatial layouts act as indicators of family activities and interactions. The literature is suggestive of the importance of spatial engagement and attachment by the family on holiday in the temporary home away from home. However, a sense emerges here of a gap between provision and consumer desires in relation to holiday accommodation.

In conclusion, much of the research on hospitality dimensions of family holidays is marketled and consumer-driven. The family experience as a whole has been largely overlooked and the voices of fathers and children particularly occluded. Family meals have received the most attention and it is the social, cultural and symbolic aspects as well as their significance in constructing family identity which have the greatest importance. The family-accommodation space dynamic has been largely neglected yet the engagement with accommodation space by a family is a highly significant event. 


\section{Study Method}

The study aims to understand the individual and collective experiences and meanings of family holidays over time for all family members. As a collective experience, investigation of family group behaviour requires a more inclusive approach, and is in accordance with interdisciplinary trends (e.g. sociology and family studies) which advocate and integrate the inclusion of children and whole-family aspects within family research (Handel, 1996, Seymour and McNamee, 2012). Whole-family methodology was adopted from family research and applied to tourism (Schänzel, 2010). Ten New Zealand families made up of 10 fathers, 10 mothers and 20 children were recruited through primary schools for the study. To maintain some homogeneity in terms of family life cycle stage and travel propensity (see Shaw et al., 2008) only families that had at least one child 8-12 years old were invited, resulting in 11 boys and nine girls, ranging from six-16 years to participate. To give a balanced gender perspective on parenthood, only two parent (male/female) families were selected which allowed for step-parents but no such "blended” families volunteered.

The participants were all white, New Zealand and middle-class, making the families relatively homogenous and not representative of the ethnic diversity of New Zealand society. The whole-family approach involved interviewing in their family homes, first, all family members together in a group interview and, then, each family member separately (children had the option of having a parent present). This was repeated three times, once before and twice after their summer holiday to capture their anticipation and short- and longer-term recollections of holiday experiences. While the contributions of the children were not as profound as adults, and this is reflected in certain statements presented in the findings, the approach provided the children with an active voice that is not often heard. 
The choice of methodology was underpinned by the philosophical perspective of interpretivism with the goal of understanding the complex world of lived experience from the point of view of those who live it (Denzin and Lincoln, 2000). A symbolic interactionist perspective was adopted for this study which focuses on the connection between symbols (i.e., shared meanings) and interactions (i.e., verbal actions and communications) and also formed the basis for a constructivist grounded theory methodology (GTM) (Charmaz, 2000) used for the analysis. This approach allowed a focus on interpersonal relations within the family group.

Case studies of families are mainly based on interviews and a small number of cases (Handel, 1991) and are almost always conducted in the home (LaRossa et al., 1994). The three stages of interviews were all digitally recorded and later transcribed. The GTM was carried out through manual coding in that data were initially coded by reading through the transcripts several times while making notes which were then sorted into themes (Charmaz, 2000). A comparative analysis of the stages was conducted after which all emerging data fitted into the main themes of family time and own time and theoretical saturation was deemed achieved (Morse, 1995). The main themes centre on togetherness in family time and also needing personal or own time, and the negotiation of the internal family group dynamics between the two. Full discussion of the methodology has been reported elsewhere (Author A, 2010). Both family meals and accommodation space are part of family time or, in other words, the ordinary and extraordinary social aspects of “being-together” on holiday (Larsen, 2013).

\section{Findings - Commensality and spatiality}

The focus of this study was on the experiential dimension of family holidays from which family meals and to a lesser extent accommodation space emerged as dominant concepts in 
the recollection of family holiday experiences. Food and accommodation form the social hospitality dimensions here. The findings are presented here under the emotive concepts of commensality and spatiality on family holidays and their resulting symbolism and memories (see Table 1). Both concepts are subdivided by the three aspects of sensory, visible and group dynamics that are discussed in turn beginning with family meals as the more debated concept in the literature. The three main aspects that emerged on commensality are: novel and nutritious food experiences; public display; and highlights; and are discussed in order of increasingly positive memories around the celebration of sociality and sociability. The three main aspects that emerged on spatiality are: hygienic and olfactory accommodation experiences; privacy; and tensions. The findings are discussed in order of increasing social tensions and negative memories around contested personal space. Selected quotes from the interviews are used to illustrate the findings with New Zealand birds as pseudonyms for family names. The quotes wholly represent the views from the families in that family meals were perceived as largely positive by all family members whereas accommodation space brought out more negative sentiments.

[insert Table 1 here]

\section{Commensality}

\section{Sensory: Novel and nutritious food experiences}

In general, the families commented on trying out different food or more novel or exotic meals on holiday which was perceived as a positive experience. This experimentation ranged from trying Turkish or Thai food to experiencing a different presentation in a Chinese restaurant. These meal experiences were generally remembered by all family members as highlights of their holidays as illustrated by the Takahe family in their final family interview: 
Girl (10): I remember that day we went to that Chinese restaurant and had that spinning thing.

Mother: Lazy Susan. I remember going to that Turkish restaurant for lunch that was nice. Everybody seemed to enjoy healthy nice food.

Boy (12): I liked the Turkish restaurant too because I never really tried a Kebab before and I really liked it.

Trying out seemingly novel or exotic meals on holiday and in unusual restaurant environments can take on special meanings as part of the away from home dimension. This fits the general understanding that holidays offer different from normal experiences and meals play a more important part in that than previously acknowledged. If a different and nutritious food experience cannot be achieved then this can result in negative hospitality experiences that affect the whole holiday. This situation is illustrated by the Pukeko family in their pre-holiday interview when recounting their shared dislike of a resort holiday in Fiji because only limited and conventional food options were offered:

We are not hot dog and take away type people. The lunches you could not get, and all you wanted was a little bit of lettuce and a bun or something like that.... They had big hamburgers with chips and goodness knows what and curries in the middle of the day. (mother)

Food also became a negative experience for the Tui family on their holiday to the USA where they struggled with finding something different than the standard fare as recounted in their final family interview:

Mother: The take away's...

Boy (11): You could squeeze the fat out.

Mother: We all stood there and thinking what can we stomach eating. 
The long-term implications of more negative food encounters particularly on children are as yet unknown but it appears that they can impact on future hospitality experiences. For example, the Pukeko family decided not to engage in any further resort holidays partly because of the uninspiring and unhealthy food choices offered there.

\section{Visible: Public display}

Commercial food experiences on holiday can also act as public displays of families. The fundamental driving force in presenting families here to an external audience is to convey the message "this is my family and it works" (Finch, 2007), as illustrated by the Pukeko family in the final individual interview by the mother:

It is always nice eating out. We always have good conversations. We have always taken the boys out with us and we expect them not to eat off the kids menu. We expect them to be adventurous, there are a couple of rules like we order it, we eat it, or make a damn good attempt. And they do, they are really good at eating out. They use their best manners and I always like to see them do that. People comment on our kids on how well adjusted they are when we go overseas. They chat to people and use their nice manners and it is good. That is quite important and hard because we can show them what we expect.

The previous commensality theme of novel and nutritious food then provides a platform for commercial meal experiences as an opportunity for acts of displaying the social interactions of family members to the public. It highlights the ongoing orchestration of family display (James and Curtis, 2010) through having family meals that are visible to and interpreted by others.

Group dynamic: Highlights 
Meal times on holiday are used as a coming together of the family that often provided the platform for conversations and other family activities such as playing cards. Meals then are about sharing common interests and were often mentioned as holiday highlights by all family members. Other highlights can be going out to a restaurant for special occasions and the sharing of stories as illustrated by the Kea family in their post-holiday family interview: Girl (11): It was my birthday and we went to [name of restaurant] and dad told us a story about how lightning struck on top of it.

Mother: It is interesting how the ones you remember are based around food.

The common experience of sharing food on holiday as a highlight can include foraging for food such as fishing and collecting mussels and the scenic beauty of the location, as illustrated by the Kereru family in their post-holiday interview:

The dining is always nice because we always sit down together. That was a very nice spot to sit outside and have a meal and have a barbecue or cook up mussels that we got off the rocks. The family dining is a nice part of the holiday. (father)

This was contrasted with the realities of family life at the Kereru home who commented that it is not often that the whole family sits together for a meal. The family meal on holiday then took on an elevated status for all family members.

The special aspect of the shared family meal on holiday was often documented through photographs and emphasises the importance placed on such experiences for the recollection of hospitality encounters. Commensality on family holiday then provided not only opportunities for conversations, storytelling, family activities and public display but also offered opportunities for positive memory creation through photographic documentation. The commensality of food experiences in a different setting from home then took on special 
significance as time rich for each other that was remembered as highlights by all family members. The findings thus emphasise the positive importance placed on sociality and sociability within the interactive family group as celebrated and different to everyday. The following findings on accommodation experiences highlight tensions within the hospitality dimensions.

\section{Spatiality}

Sensory: Hygienic and olfactory accommodation experiences

Spatiality can be a sensory experience that is perceived and remembered differently by different family members. Negative sensory accommodation experiences can particularly affect the memories of children and potentially impact on their future enjoyment of similar hospitality establishments as illustrated by the Pukeko family in the pre-holiday family interview recalling the incident years after the actual encounter:

Boy (11): We do not like really dirty camping grounds.

Boy (13): What was that one where there was that horrible smell all the time?

Father: It is not the sort of thing you are supposed to remember from a holiday. Mother: I do not remember it smelling.

What emerges is that children are less prepared to forget about poor experiences as those sensory memories were repeatedly mentioned making them particularly relevant. This is illustrated in the Takahe post-holiday family interview:

Girl (10): I think our worst holiday ever was when we stayed at the farm.

Boy (12): When will you get over that?

Girl (10): It [the room] was next to this wool shed and there was this sheep chute which I thought was a slide and it smelt. It was not really nice. 
Mother: Also I really enjoyed that.

Negative sensory experiences then can cloud the long-term perception of certain accommodation choices illustrating differences in recollections that individual family members can have of accommodation experiences. For children in particular, negative olfactory and hygienic spatiality experiences may enter their long-term memory and highlight that children can be more sensitive to heightened sensory experiences than parents.

Visible: Privacy

Most families stayed at campgrounds in either their own tents or in self-contained cabins.

Other accommodation used by the families was motels, commercial holiday home, apartment hotel or own boat which for all families was smaller than at home. Positive spatiality experiences concerned with private and personal space are connected with either having adequate space for the whole family or the ability to create additional private space. Several families commented on negotiating space on holiday by erecting tents for their children which created extra space for everyone. This practice is illustrated by the Tui family where the parents stayed in a rented cabin and the three children each had their own tent:

The fact that we had the cabin and tents because that way I didn't have the: 'you get out of my room'. I didn't hear that because they had their own bedroom per se. (Post-holiday family interview, mother)

Where space was at a premium and it was impossible to create extra space negative spatial experiences could arise as illustrated by 10 year old Fantail girl in the final individual interview on her experience of confinement on a boat which meant that she preferred to stay at home: 
Spending the whole time on the boat which is just a wee bit bigger than this room. It is quite cramped and you get quite bored easily.

Overcrowding in the accommodation setting meant that children and adults were together at all times, without any opportunity for privacy, and this gave rise to feelings of dislike and disengagement. The lack of private and personal space within a shared spatial environment not only negatively affects holiday memories but can also impact negatively on family group dynamics as illustrated within the next aspect.

\section{Group dynamic: Tensions}

When sufficient accommodation space is available for all family members then this has little influence on length of stay. Cramped spatial experiences, however, can bring out more negative group dynamics and highlight problems with sleep that limit the time families want

to spend there. A particular negative dynamic was the sharing of bedrooms for siblings which negatively impacted on the spatial experience of the parents or brought out the rivalry between children as illustrated by the Takahe family:

The motel unit was quite small. I think in terms of that it [five day stay] was probably the right length of time. The other thing was that the kids had to share a room and sometimes that doesn't work out so well these days. (Post-holiday individual interview, father)

Of particular concern was the settling of younger children in shared bedrooms which impacted negatively on the spatiality experience of the rest of the family. The sharing of accommodation spaces is further negatively commented on by children themselves as illustrated by the Kea sisters (aged 7 and 10) who shared a bunk bed on holiday: 
I didn't enjoy how I was at the bottom bunk and couldn't really sleep. It was always about 9pm when I went to bed. And we switched one night but then [sister] kept wriggling and the poles kept moving and it is kind of difficult for me to sleep. (Final interview, 10 year old girl) Sharing space, especially in terms of bedrooms, with younger siblings then gave rise to feelings of discomfort and conflict.

The concept of spatiality on family holidays illustrates not only the more private and emotive aspects of sharing accommodation space but also how spatiality is negotiated and experienced differently by individual family members. Emotive responses to accommodation spaces may act as a lightening conductor for human relationships and be remembered negatively. Also, accommodation experiences are largely dependent on the availability of personal space as accommodation environments on holiday are usually more cramped than at home. The perceived lack of spatiality then symbolises the more contested nature of holidays which can negatively impact on the quality of sleep, length of stay and memories.

\section{Discussion}

The study has located perceptions and the importance of social hospitality within the totality of the family holiday experience and has found hospitality experiences to be highly significant in relation to major themes of sociality, the sociability of family meals and social tensions arising around personal space. The concepts arising of commensality and spatiality provide insights into family dynamics as well as sensory dimensions and memory formations that highlight inherent paradoxes and enduring implications. Family holiday meals are generally expected to be more exotic or novel, and not standard fast-food, which can be related to unusual eating environments (Yan, 1997) but also reflect cultural expectations that foreign foods consumed on holiday are more desirable than everyday or local based (Cohen 
and Avieli, 2004). In relation to meals and food environments while on holiday, it is the differences that children remember most compared to eating at home (Cullingford, 1995).

Commensality on holiday is also based on the notion of proper or nutritious food eaten together as a symbol of what a proper family does (Curtis et al., 2010) and a sign of good parenting (James and Curtis, 2010). Recognition is necessary that with advanced age and through previous exposure of more varied food, children are likely to share the more sophisticated adult tastes of their parents. The provision of nutritionally limited and bland food experiences on holiday then do not reflect the increasingly diversified and culinary advanced tastes of contemporary Western families (Carr, 2011) and their food moralities (Curtis et al., 2010). Encountering bad food experiences can prove particularly memorable for children.

Increased opportunities for interactions at holiday meals allows for a myriad of types of communication and activities, including sociability and socialization (Danesi, 2012) not usually available in everyday life. The study highlights the role of hospitality in family bonding and is supportive of perceptions of hospitality as acting as a kind of social glue (Putnam, 2000). The commensality of those food experiences can take on a more symbolic and ritualistic character that is more enduring (Fiese et al., 2002) and also influences the degree of emotional engagement of family members (Lashley et al., 2003). This is aided by the scenic beauty of where the meals take place (Lashley et al., 2003) and through photographic documentation.

This form of communal event and heightened social experience confers status on holiday meals as special occasions that transcends their more utilitarian value. Commercial meal 
opportunities allowed families to show that they were capable of acting like a family in a public setting. Display is an important part of the nurturing and development of relationships so that the family-like qualities are positively established (Finch, 2007). The social practice of “doing family things” such as shared meals (rather than "being” a family) does then get constituted as a family practice on holiday which differs from the routines of daily life. Further, such meals aid in the development of a sense of a public family identity that changes over time. This is based on an interaction between the family itself as an audience and also the public audience and their interpretation and acceptance of the family display.

Spatiality as felt accommodation space on family holidays reveals needs for privacy in dealing with group dynamics. The more confined living and especially sleeping arrangements in holiday accommodations highlight embodied family practices (Morgan, 2011) through individual needs for “own space” and potentials for conflicts when privacy cannot be achieved. Embodiment, or the sense of having or being a body, is brought about here through the physical co-presence of family members of different ages, generations and genders within relatively bounded spaces (Morgan, 2011). Social tensions arise out of family group members having to share limited accommodation spaces which can lead to bodily density (Morgan, 2011) resulting in problems with sleep and reduced holiday stays.

The study further underlines the potential for conflict and stress due to the inadequacies of facilities (Backer and Schänzel, 2013) or shared bedrooms (Obrador, 2012) in holiday accommodations which are similar to issues arising in emergency accommodation (Halpenny et al., 2002). It seems that child-friendly accommodation at present often means the provision of high chairs, swimming pool and suchlike rather than space for older children. It is not surprising therefore that families often choose holiday accommodation with more 
accommodation space, home-like facilities and less restrictions (Mottiar and Quinn, 2012). The study highlights the importance of adequate personal and family space as well as the importance of accommodation space that recreates a type of family home and helps to explain the growth of self-contained apartments (Lynch, 2005).

The family room on holiday acts as a contrast to the increasing private space available to family members within the home environment (Graesch, 2004). The active creation of personal accommodation space on holiday is one of the ways of circumnavigating negative group dynamics along with staking out one's territory. These are means to replicate the privacy arrangements that are found at home and creating a "home away from home" (Haldrup, 2004). Rather than holidays being a departure from everyday life, the negotiation of accommodation space requires similar arrangements to home but in a different setting. These negotiations of accommodation space are learnt from past experiences highlighting the influence of negative memories on present holiday behaviour and the contested nature of holiday spatiality.

Further, the encounter of bad sensory and unhygienic accommodation experiences proved particularly memorable for children and influenced their future choices in that they were unwilling to repeat similar lodgings. Including bad food experiences, this emphasises that children are generally less prepared to overlook mediocre and poor hospitality experiences and also embodiment and sensory experiences are particularly relevant for children (Small, 2008). Embodiment introduces other senses such as smell and taste into tourism and hospitality studies which arguably have been neglected to date and highlights the repercussions of reliving positive and negative holiday memories and sensations. 


\section{Conclusion}

The study presented here allows insights into the antithetical nature of hospitality experiences on family holidays. The concept of commensality emphasises the social, emotional and celebratory importance placed on family meals on holiday while the concept of spatiality highlights the contested need for privacy on holiday. Family holidays are marketed and perceived as opportunities for bonding and togetherness (Larsen, 2013) in which meals play an important part. The increased frequency of commensality on holiday taps into the idea of gaining social or family capital through sociality, sociability and public display that can serve as memorable highlights. Family capital is used here to reflect the strengthening of relationships between parents and children and the social identification that is facilitated on holiday (Minnaert et al., 2009).

Family holiday commensality then takes on a more symbolic, public and celebrated role and is about desired togetherness. Spatiality on holiday is about issues of bodily density, privacy and sleep as a collective entity (Valtonen \&Veijola, 2010) that are contested and can result in conflicts highlighting family group dynamics of enforced togetherness. Both hospitality dimensions emphasise the long-term repercussions of poor accommodation or food experiences for children because of their heightened sensory memory or embodiment which introduces different bodily experiences into the study of tourism. This is noteworthy as catering to the young family tourist is a significant market segment.

Examining the experiences of all family members on holiday through a whole-family approach provides opportunities to explore how transactions of food, accommodation and the social interactions associated with hospitality create positive and negative spaces through desired togetherness and enforced togetherness. Examining the various manifestations of 
hospitality can help to contextualise the workings of societies, cultures and their spaces (Bell, 2007). Exploring the food and accommodation experiences on holiday from the perspective of all family members reveals how commensality, spatiality and embodiment create positive and negative memories that have repercussions for future hospitality encounters. The wholefamily approach, as an innovative qualitative research strategy, allows moving away from primarily individual perspectives that have dominated tourism research and gives greater emphasis to the importance of understanding the group experience, children's experiences and collective consumption of tourism and hospitality.

The paper has added to the literature exploring the sociology of hospitality and tourism by providing insights into the family holiday. Examining these aspects can enable tourism research to contribute to broader academic debates about families, time, space and societies. Further, by examining how private, commercial and social dimensions of hospitality interact through a more critical and holistic approach, it can help to develop positive and socially sustainable business practices. Taking new research approaches can reveal better understandings of the complex and socially important process of hospitality (Braithwaite, 2003) in particular with regards to the encounters for children.

The study suggests a number of research avenues. The study here has focused upon the traditional family unit in a Western country but studies are needed representative of the diversity of family groups. The homogeneity of the sample is a recognised limitation and culturally more diverse samples repeating the study would be beneficial. With changes in the composition of world family tourism markets, in recognition of sociological and cultural differences in perspectives on hospitality, for example, in relation to the growing 
international Chinese market (Yeoman, 2008), it is important to have more sociologically and culturally informed studies of family holiday practices.

The family holiday research agenda could usefully be developed in relation to sleep within family arrangements, as part of the new research on the sociology of sleep (Williams, 2005). While there is a tendency to group children together as having similar needs, we need to better understand the hospitality requirements of children of different ages, from toddlers to teenagers. The study suggests commensality is seen mostly as highlights, however it would be useful to better understand meals as contested times and also the negative aspects of shared eating such as children's resentment towards family display. There is a need to explore the importance of adult memories of childhood experiences of family holiday hospitality experiences and their impact on holiday decisions. It would be helpful to better understand the idea of the holiday as an antidote to the fragmentation of daily life at home. Greater attention is also needed to embodied experiences of hospitality. Finally, more longitudinal studies of families are needed in order to deepen our understanding of the longterm implications of experiences of holiday commensality and spatiality.

\section{References}

BACKER, E. \& SCHÄNZEL, H. 2013. Family holidays - vacation or obli-cation? Tourism Recreation Research, 38, 159-173.

BEARDSWORTH, A. \& KEIL, T. 1997. Sociology on the menu: an invitation to the study of food and society, London, Routledge.

BELL, D. 2007. The hospitable city: social relations in commercial spaces. Progress in Human Geography, 31, 7-22. 
BELL, D. \& VALENTINE, G. 1997. Consuming Geographies: We are where We eat, London, Routledge.

BILDTGÅÅD, T. 2010. What it means to "eat well" in France and Sweden. Food and Foodways, 18, 209-232.

BLAKE, M., MELLOR, J., CRANE, L. \& OSZ, B. 2009. Eating in time, eating up time. In: JACKSON, P. (ed.) Changing Families, Changing Food. Basingstoke: Palgrave MacMillan.

BLICHFELDT, B. S. \& MIKKELSEN, M. 2013. Vacability and sociability as touristic attraction. Tourist studies, 13, 235-250.

BLICHFELDT, B. S., PEDERSEN, B. M. L., JOHANSEN, A. \& HANSEN, L. 2011. Tweens on Holidays. In-Situ Decision-making from Children's Perspective. Scandinavian Journal of Hospitality and Tourism, 11, 135-149.

BRAITHWAITE, R. W. 2003. Five meals in the forties: Perspectives on hospitality under extreme circumstances. Tourism Review International, 7, 61-66.

BROEGE, N., OWENS, A., GRAESCH, A. P., ARNOLD, J. E. \& SCHNEIDER, B. 2007. Calibrating measures of family activities between large- and small-scale data sets. Sociological Methodology, 37, 119-149.

BURGOYNE, J. \& CLARKE, D. 1983. You are what you eat: food and family reconstitution. In: MURCOTT, A. (ed.) The Sociology of Food and Eating: Essays on the Sociology of Food. Aldershot, UK: Gower.

CARR, N. 2011. Children's and Families' Holiday Experiences, London and New York, Routledge.

CHARMAZ, K. 2000. Grounded theory: Objectivist and constructivist methods. In: DENZIN, N. K. \& LINCOLN, Y. S. (eds.) Handbook of Qualitative Research. 2nd ed. Thousand Oaks, CA: Sage. 
COLLINS, D. \& KEARNS, R. 2010. 'Pulling up the Tent Pegs?' The Significance and Changing Status of Coastal Campgrounds in New Zealand. Tourism Geographies: An International Journal of Tourism Space, Place and Environment, 12, 53 - 76.

CULLINGFORD, C. 1995. Children's attitudes to holidays overseas. Tourism Management, $16,121-127$.

CURTIS, P., JAMES, A. \& ELLIS, K. 2010. Children's snacking, children's food: food moralities and family life. Children's Geographies, 8, 291-302.

DANESI, G. 2012. Commensality in French and German young adults: an ethnographic study. Hospitality \& Society Journal, 1, 153-172.

DAVIDSON, P. 1996. The holiday and work experiences of women with young children. Leisure Studies, 15, 89-103.

DAVIDSON, R. \& GAUTHIER, A. H. 2010. A cross-national multi-level study of family meals. International Journal of Comparative Sociology, 51, 349-365.

DEEM, R. 1996. Women, the city and holidays. Leisure Studies, 15, 105-119.

DENZIN, N. K. \& LINCOLN, Y. S. (eds.) 2000. Handbook of Qualitative Research, Thousand Oaks, CA: Sage.

DOUGLAS, M. 1975. Deciphering a meal. Daedalus, 101, 61-81.

DOUGLAS, M. 1991. The idea of a home: a kind of space. Social Research, 59, 287-307.

FIESE, B. H., TOMCHO, T. J., DOUGLAS, M., JOSEPHS, K., POLTROCK, S. \& BAKER, T. 2002. A review of 50 years of research on naturally occurring family routines and rituals: Cause for celebration? Journal of Family Psychology, 16, 381-390.

FINCH, J. 2007. Displaying Families. Sociology, 41, 65-81.

FRUH, S. M., FULKERSON, J. A., MULEKAR, M. S., KENDRICK, L. A. J. \& CLANTON, C. 2011. The Surprising Benefits of the Family Meal. The Journal for Nurse Practitioners, 7, 18-22. 
GIORGI, S., PADIGLIONE, V. \& PONTECORVO, C. 2007. Appropriations: Dynamics of Domestic Space Negotiations in Italian Middle-Class Working Families. Culture \& Psychology, 13, 147-178.

GRAESCH, A. P. 2004. Notions of family embedded in the house. Anthropology News, 45, 20.

GRAM, M. 2005. Family holidays. A qualitative analysis of family holiday experiences. Scandinavian Journal of Hospitality \& Tourism, 5, 2-22.

HALDRUP, M. 2004. Laid-back mobilities: Second-home holidays in time and space. Tourism Geographies, 6, 434-454.

HALPENNY, A. M., KEOGH, A. F. \& GILLIGAN, R. 2002. A Place for Children? Children in Families living in Emergency Accommodation: The Perspectives of Children, Parents and Professionals. Reports, Paper 14.

HANDEL, G. 1991. Case study in family research. In: FEAGIN, J. R., ORUM, A. M. \& SJOBERG, G. (eds.) A Case for the Case Study. Chapel Hill: The University of North Carolina Press.

HANDEL, G. 1996. Family worlds and qualitative family research: Emergence and prospects of whole-family methodology. Marriage \& Family Review, 24, 335-348.

HEIMTUN, B. 2010. The holiday meal: eating out alone and mobile emotional geographies. Leisure Studies, 29, 175-192.

HILBRECHT, M., SHAW, S. M., DELAMERE, F. M. \& HAVITZ, M. E. 2008.

Experiences, perspectives, and meanings of family vacations for children. Leisure/Loisir, 32, 541-571.

HOLLOWAY, S. L. \& VALENTINE, G. 2000. Spatiality and the New Social Studies of Childhood. Sociology, 34, 763-783. 
HOLTZMAN, J. 2010. Remembering bad cooks: sensuality, memory, personhood. The Senses and Society, 5, 235-243.

JAMES, A. \& CURTIS, P. 2010. Family displays and personal lives. Sociology, 44, 11631180.

LAROSSA, R., BENNETT, L. A. \& GELLES, R. J. 1994. Ethical dilemmas in qualitative family research. In: HANDEL, G. \& WHITCHURCH, G. G. (eds.) The Psychosocial Interior of the Family 4th ed. New York: Aldine de Gruyter.

LARSEN, J. R. K. 2013. Family Flow: The Pleasures of “Being Together” in a Holiday Home. Scandinavian Journal of Hospitality and Tourism, 1-22.

LASHLEY, C., LYNCH, P. \& MORRISON, A. (eds.) 2007. Hospitality: A social Lens, Oxford: Elsevier.

LASHLEY, C., MORRISON, A. \& RANDALL, S. 2003. My most memorable meal ever! Hospitality as an emotional experience. In: SLOAN, D. (ed.) Hospitality, Leisure and Tourism: Culinary Taste: Consumer Behaviour in the International Restaurant Sector. Jordan Hill: Butterworth-Heinemann.

LEFEBVRE, H. 1991. The Production of Space, Oxford, Basil Blackwell.

LEHTO, X. Y., LIN, Y.-C., CHEN, Y. \& CHOI, S. 2012. Family Vacation Activities and Family Cohesion. Journal of Travel \& Tourism Marketing, 29, 835-850.

LYNCH, P. A. 2005. Reflections on the Home Setting in Hospitality. Journal of Hospitality \& Tourism Management, 12, 37-49.

MENNELL, S., MURCOTT, A. \& VAN OTTERLOO, A. 1992. The Sociology of Food: Eating, Diet and Culture, London, Sage.

MESTDAG, I. \& VANDEWEYER, J. 2005. Where has family time gone? In search of joint family activities and the role of the family meal in 1966 and 1999. Journal of Family History, 30, 304-323. 
MINNAERT, L., MAITLAND, R. \& MILLER, G. 2009. Tourism and social policy: The value of social tourism. Annals of Tourism Research, 36, 316-334.

MINTEL 2004. Family Holidays, Leisure Intelligence, June. June ed. London: Mintel International Group.

MOORE, J. 2000. Placing home in context. Journal of Environmental Psychology, 20, 207217.

MORGAN, D. 2011. Rethinking Family Practices, Basingstoke, Palgrave Macmillan.

MORSE, J. M. 1995. The significance of saturation. Qualitative Health Research, 5, 147149.

MOTTIAR, Z. \& QUINN, D. 2012. Is a self-catering holiday with the family really a holiday for mothers? Examining the balance of household responsibilities while on holiday from a female perspective. Hospitality \& Society, 2, 197-214.

MUNRO, M. \& MADIGAN, R. 1999. Negotiating space in the family home. In: CIERAAD, I. (ed.) At Home: An Anthropology of Domestic Space. New York: Syracuse University Press.

OBRADOR, P. 2012. The place of the family in tourism research: Domesticity and thick sociality by the pool. Annals of Tourism Research, 39, 401-420.

PRITCHARD, M. P. \& HAVITZ, M. E. 2006. Ratios of tourist experience: It was the best of times, it was the worst of times. Tourism Analysis, 10, 291-297.

PUTNAM, R. D. 2000. Bowling Alone, New York, Simon \& Schuster.

SCHÄNZEL, H. A. 2010. Whole-family research: Towards a methodology in tourism for encompassing generation, gender, and group dynamic perspectives. Tourism Analysis, 15, 555-569.

SCHÄNZEL, H. A. \& SMITH, K. A. 2011. The absence of fatherhood: achieving true gender scholarship in family tourism research. Annals of Leisure Research, 14, 129-140. 
SCHÄNZEL, H., YEOMAN, I. \& BACKER, E. (eds.) 2012. Family Tourism:

Multidisciplinary Perspectives, Bristol: Channel View.

SEYMOUR, D. 1983. The social functions of the meal. International Journal of Hospitality Management, 2, 3-7.

SEYMOUR, J. \& MCNAMEE, S. 2012. Being parented: Children and young people's engagement with parenting activities. In: WALDEN, J. \& KAMINSKI, I.-M. (eds.) Learning from the Children: Culture and Identity in a Changing World. Oxford: Berghahn.

SHAW, S. M., HAVITZ, M. E. \& DELAMERE, F. M. 2008. I decided to invest in my kids' memories: Family vacations, memories, and the social construction of the family. Tourism Culture \& Communication, 8, 13-26.

SMALL, J. 2005. Women's holidays: Disruption of the motherhood myth. Tourism Review International, 9, 139-154.

SMALL, J. 2008. The absence of childhood in tourism studies. Annals of Tourism Research, 35, 772-789.

SOBAL, J. \& NELSON, M. K. 2003. Commensal eating patterns: a community study. Appetite, 41, 181-190.

VALTONEN, A. \& VEIJOLA, S. 2010. Sleep in tourism. Annals of Tourism Research, 38, 175-192.

VAN MANEN, M. 1990. Researching Lived Experience: Human Science for an Action Sensitive Pedagogy, London, Ontario, Canada, The University of Western Ontario. VISITBRITAIN 2011. Inbound Visitor Statistics.

WALLS, A. R., OKUMUS, F., WANG, Y. \& KWUN, D. J.-W. 2011. An epistemological view of consumer experiences. International Journal of Hospitality Management, 30, $10-21$. 
WILLIAMS, S. J. 2005. Sleep and Society: Sociological Ventures into the (un)known, Milton Park, UK, Routledge.

WOOD, R. 1995. The Sociology of the Meal, Edinburgh, Edinburgh University Press.

YAN, Y. 1997. Of Hamburger and social Space: Consuming McDonald's in Beijing, Abingdon, Routledge.

YEOMAN, I. 2008. Tomorrow's Tourist: Scenarios \& Trends, Oxford, UK, Elsevier. 
Table 1. Social hospitality dimensions on family holidays

\begin{tabular}{|c|c|c|}
\hline Food & Hospitality dimensions & Accommodation \\
\hline Shared meals & Family hospitality on holiday & Shared accommodation space \\
\hline Commensality & Emotive concepts & Spatiality \\
\hline novel and nutritious & sensory & hygienic and olfactory \\
\hline public display & visible & tensions \\
\hline highlights & group dynamics & contested \\
\hline celebrated & symbolism & negative \\
\hline positive & memories & \\
\hline
\end{tabular}

